\title{
Bird Observations from Uranium City
}

\author{
By Thomas Heaslip, Uranium City, Sask.
}

I have been a resident of the Uranium City area for two and a half years, arriving in 1956 from Newtonards, Northern Ireland, where I was a member of the Copeland Islands Bird Observatory Society. A former residence of three and a half years in the Hudson Valley highlands of New York State provided my first opportunity for becoming acquainted with North American birds.

The winter residents in this area seem to be few in numbers: we have the Common Raven, Willow Ptarmigan, Boreal Chickadee, Gray Jay, Hairy Woodpecker, and an occasional small flock of redpolls. Towards the end of March I have noticed small parties of Pine Grosbeaks flying low in a northerly direction, their threesyllabled whistle being pleasant to hear after the long winter silence, broken now and then by the harsh croak of the raven. I have often been puzzled by the fact that, both in spring and autumn migrations, I have never seen any Pine Grosbeaks in male plumage, and I have thought that they all seemed to be either females or immature males. What, I wonder, has been the experience of other observers in this area with respect to these birds?*

The junco always seems to be the first real harbinger of spring as its cheerful little notes often accompany the first patter of spring raindrops and the hurrying bands of northward bound caribou.

May is the month I most enjoy; mosquitoes are still too few to be a real nuisance, the spring migrants are pouring in, and every little lake seems to be entertaining à party of ducks, swimming a few yards out from the melting ice along the edges. I find that wild ducks are curious about people, at least up here on the northland lakes; while sitting or crouching motionless partly under cover of a willow or pine at the lake's edge, I have had small groups of ducks come to within a few yards of me. Many Buffleheads have given me great pleasure in this way; they appear to be the commonest duck on the lakes here in spring just after the thaw. Horned Grebes accompany the ducks on the lakes. One of the strangest bird calls I have ever heard came from a pair of large grebes which I took to be Red-necked Grebes.

The large gulls (Herring Gulls?) arrive here about the first of May and depart in November. I am not aware of any nesting colonies, but I have noticed that towards the end of their resident period, the number of immatures increases and that the immatures are the last to leave.' This may just be due to the camp's garbage dump having a greater attraction for the immature birds. Here at the garbage dump during the month of November I recorded the only Magpie that $I$ have seen in the area in two and a half years. It stayed for about three weeks, then disappeared after the first cold spell. It was also at this garbage dump that I observed the Whimbrel included in my general list.

On May 27, 1958, as I was watching a pair of sapsuckers near a stream, an immature Golden Eagle suddenly appeared flying low over the tree tops, mobbed by a pair of ravens. Eventually it got rid of the ravens by circling to a great height, then it disappeared in an easterly direction. Four days later I enjoyed watching an adult Bald Eagle soaring over Beaverlodge Lake.

Hawks do not seem to be common in this local area, with the exception of the little Sparrow Hawk, this being the only species observed throughout the summer. I understand that a pair of Peregrine Falcons stayed last spring near the Uranium City Hospital and probably nested, but I did not see these birds myself. My observations are ordinarily confined to an area roughly three miles from camp, which is situated about eleven miles to the south of Uranium City. An exception was a brief visit to a sheltered inlet of Lake Athabasca last June where I saw a large flock of Common Mergansers.

* One of our members, E. N. Shannon, who used to live at Uranium City, says that he has personally always seen the males and females together.-Ed. 
I hope that in the future, a greater degree of protection may be afforded the birds of Northern Saskatchewan. In the spring season I have come across ravens and grebes killed by .22 bullets. Perhaps some of the people in our northern camps, particularly newcomers to the country, are not even aware of bird protection laws. It would help, I think, if the provincial government could see that copies of game and bird protection laws were posted conspicuously in every camp.

SPECIES LIST: Common Loon, Red-necked Grebe, Horned Grebe, Canada Goose, Mallard, Pintail, Green-winged Teal, American Widgeon, Ring-necked Duck, Lesser Scaup, Bufflehead, Surf Scoter, Common Merganser, Golden Eagle, Bald Eagle, Sparrow Hawk, Spruce Grouse, Willow Ptarmigan, Sharp-tailed Grouse, Semipalmated Plover, Killdeer, Common Snipe, Whimbrel, Spotted Sandpiper, Greater Yellowlegs, Pectoral Sandpiper, Least Sandpiper, Northern Phalanope, Herring (?) Gull, Common Nighthawk, Belted Kingfisher, Yellow-shafted Flicker, Pileated Woodpecker, Yellow-bellied Sapsucker, Hairy Woodpecker, Downy Woodpecker, Northern Three-toed Woodpecker, Least Flycatcher, Olive-sided Flycatcher, Barn Swallow, Gray Jay, Black-billed Magpie, Common Raven, Boreal Chickadee, Robin, Hermit Thrush, Swainson's Thrush, Ruby-crowned Kinglet, Solitary Vireo, Tennessee Warbler, Orange-crowned Warbler, Myrtle Warbler, Red-winged Blackbird, Rusty Blackbird, Hoary Redpoll, Common Redpoll, Slatecolored Junco, White-crowned Sparrow, Whitethroated Sparrow, Lincoln's Sparrow, Swamp Sparrow.

\section{NORTHERN THR E E - T O E D WOODPECKER AT YORKTON.-} The first definite record of a Threetoed Woodpecker for Yorkton was obtained on October 28, 1958, when three grade four pupils of Miss Pauline Summers at Simpson School found a Northern (American) Threetoed Woodpecker lying dead on the ground on Marion Street near the C.N.R. tracks. It was clutching a leaf in its feet. It has been made into a study skin by Dr. Houston. The girls were Georgina Demchuk, Janet Parno and Caroline Crandall.Stuart Houston, Yorkton.

\section{HOODED MERGANSERS}

YORKTON. - Several flocks of Hooded Mergansers were seen last fall at Leech and Crescent Lakes, south of Yorkton. A beautiful adult male and a female were shot at Leech Lake on October 20, 1958, by Bert Moore and a female was shot at Chas. Maddaford's, at the Crescent or "Maple Island" Marsh by Dr. C. J. Houston on October 25, 1958.
Only two records of this species were listed in Houston's 'The Birds of the Yorkton District. Saskatchewan (Can. Field-Nat. 63, 1949, p. 215-241). Two subsequent records are for one shot September 18, 1951, at Rousay Lake by $R$. M. Baldwin, and an adult female sighted by Stuart and Mary Houston, half a mile north of the York Lake Golf Course on June 24, 1952.-Stuart Houston, Yorkton.

\section{INTERESTING BLACK DUCK} RECORD.-I have a Black Duck record which I believe is of great interest. \#576-19325 was banded at Kutawagan Lake on July 19, 1957, as a flightless adult male. It returned to moult at the same lake next summer and was recaptured on July 9, 1958. This may only be a coincidence, or perhaps Black Ducks are not the random wanderers we thought they were.-Tim Sterling, Ducks Uulimited.

RAT MOBBED BY HOUSE SPARROWS. - In mid-January, 1959, I glanced out of my kitchen window at the flock of about two dozen sparrows which feeds each morning in my back yard at 3251 Angus Street. I was startled to see a rat running along the back fence. "Oh! Oh!" I thought, "I will be asked to stop feeding the sparrows in case I am encouraging rats. The poor little mites! And such a cold winter!"

However, there was no need for concern because the rat was kept away from the feeding area by the birds themselves. As soon as the rat started towards the birds' food, about ten sparrows swooped down on him en masse and he quickly headed toward the back gate.

I have been putting food out for birds every morning for several years, winter and summer-bread, wheat, raisins, fat. The birds' feeding area is on the ground and the snow is shovelled off by my son whenever it fills in during the winter. The rat was never allowed to reach the feeding area, though once while I watched he came close. I observed these happenings for two mornings, then the rat disappeared and I have not seen him since. There has been a heavy fall of snow since, but no rat tracks-of that I am sure. There have certainly been none near the feeding area.-Holly Wallace, Regina. 